\title{
The evaluation of university's impact on «human resource potential» of alumni
}

\author{
Iuliia Obukhova ${ }^{1,{ }^{*}}$, Dmitrii Popov ${ }^{1}$, Anna Tanova ${ }^{1}$, and Veronika Fokina ${ }^{1}$ \\ ${ }^{1}$ Peter the Great St. Petersburg Polytechnic University, 195251 St.Petersburg, Russia
}

\begin{abstract}
This paper considers university educational environment to be an important factor in the development of students' organizational and managerial competence. The authors discuss the approaches to the educational environment of the university, analyze its parameters and characteristics and study the connection between the developmental educational environment and a high level of managerial competence attained by technical university graduates. The authors rely on the environmental approach which allows them to assess the impact of the educational environment on students' organizational and managerial competence taking into account the analysis of empirical data obtained by monitoring methods of sociological research. This method also made it possible to improve self-organization and self-management skills of students and to achieve a high level of resilience both on the environmental and personal level.
\end{abstract}

\section{Introduction}

Modern universities are highly dependent on feedback from their graduates. Successful communication allows them to build long-term loyalty, which leads to the formation of joint projects, a corporate culture and lobbying institutions. Each successful university graduate becomes part of the university's added brand values. But in reality, only the most active graduates maintain a long-term relationship with the organization, and the university's task is to develop the most effective communication mechanisms and build trusting partnerships. Organizational forms of interaction between graduates and the university are largely based on the creation of organizational forms in the form of graduate clubs, departments for working with graduates and their analogues [1-3]. In this study, the authors consider relationships with graduates through the prism of special communications, the purpose of which is to search and build long-term relationships with the most active and loyal graduates, as well as the formation of additional feedback value based on the concept of "human resource potential".

"Human capital" and "human resource potential" are two interrelated concepts that imply the perception of a person with his abilities, knowledge, skills and experience as one of the key elements of the technical and economic development of society [4-6].

It is a person with the totality of his talents and knowledge that is considered as the driving force of modern progress. An index called the Human Development Index is used

* Corresponding author: julietobu@gmail.com 
by the UN to study state development and cross-country comparisons. It includes not only data on life expectancy, inequality and income, but also data on education. Thus, it turns out that intellectual abilities, creative abilities, educational level, professional experience of a person are an important element of modern socio-economic development and the value of this element by participants in socio-economic relations at various levels is fully recognized. But in its formation, of course, not only the higher education system is involved, but also the family, school, experience of professional activity, communication in the professional community, etc.

On the other hand, the sphere of production and management is constantly busy with the problem of finding and hiring workers, considering them from the point of view of "human resource potential". The concept of "human capital" can be found in the works of both sociologists and economists. Universities have always acted as centers for the reproduction of competencies, knowledge and skills. Modern universities have received a new line of activity related to the retraining of personnel in accordance with the challenges of the new economy, and in addition have embarked on the difficult path of forming practice-oriented areas of educational activity, in accordance with the requirements of state, business and public institutions. In this regard, graduates in modern conditions again turn to universities as customers and consumers of new educational services, according to the modern understanding of "human capital".

In this work, the authors are interested in whether alumni perceive their studies at the Peter the Great St. Petersburg Polytechnic University (SPbPU) as a tool that helped them develop their abilities and reveal their potential in the future and occupy a worthy place in the professional community. In other words, we try, without using the terms "human capital" and "human resource potential" in our questionnaire, to determine whether alumni perceive their studies at the university as an element or even a source of their professional success.

A number of researchers, including V. Yasvin, believe that the educational environment is a system of conditions for individual development, which also provides further necessary opportunities for successful functioning in the social environment [7].

In this regard, in this article we are interested in whether the Alumni share this point of view. Do they believe that SPbPU played a significant and positive role in their formation as professionals, does the university (or higher education in general) play a significant role in the development of "human capital" from the point of view of graduates of the Polytechnic University. Studies of student and graduate satisfaction in 2017 and 2018 conducted at SPbPU tell us that at least a third of those surveyed at the time of the study had certain expectations from the specialty they were receiving when they entered the first year of study (another $40 \%$ found it difficult to answer this question), while $64 \%$ are satisfied with the training, and $65 \%$ believe that it meets their expectations, $68 \%$ have an idea of what kind of workplace they will take after graduation; $64 \%$ after graduation are going to work in their specialty and $82 \%$ confirmed the fact of a conscious choice of the preparation / specialty direction [8].

Studies tell us that the educational environment plays a significant role in the formation of certain skills among students and in addition to the main specialty, in particular managerial, communicative competencies, etc. [9]. M. Ababkova, N. Pokrovskaya and D. Fedorov in their article substantiate the idea that «from the consumer point of view, universities should create specific value: the increase of the intellectual components of human capital. These complex functions are interconnected». The article justifies how educational services may push the intellectual capital growth and provide the transfer of Knowledge by transmission of culture during the process of university education [10].

However, it seems important if the graduates see the role of their university in the formation of a wider range of skills, competencies, and character traits, for example, do 
they think that their training influenced the formation of soft skills, broadened their horizons, and defined their professional ambitions, social identity; whether the university helped them to see career prospects, the formation of communication and management skills, etc. It can be noted that the formation of graduate's social identity is influenced by many factors - from satisfaction with training, as mentioned above, to demonstrating that you are a member of a certain community (in this case, the alumni community) using a selfie [11].

In addition, other researchers, for instance, Lesher and Kromov, characterize students of technical universities as those who have a high level of non-verbal intelligence, a high level of logical and analytical thinking, high speed and accuracy of mental operations, as well as critical thinking [12].

Thus, students of technical universities can be characterized as highly intelligent, active, capable of solving complex professional problems that require strain of thought. If we take this very complementary image of graduates as a basis, it seems important to find out whether graduates, as representatives of the professional community, are interested in the problem of development of human resource potential, and whether they consider current students and young graduates as human capital that can be used for development of their own projects, and the Polytechnic University as a "workers' creator", as we have been told about research from previous years [13]. The problem of the formation of additional competencies, in addition to the basic professional skills for many universities, today seems to be an urgent task [14-17].

Also in the context of the graduates' attitude to the role of education in general and its alma mater in particular in the formation of their abilities and skills, we are also interested in the problem of communication between graduates and the university. Based on previous studies, we believe that graduates, in general, have a positive attitude towards maintaining communication with alma mater, as well as with other graduates, they do not consider the university as a completed stage, some of them are ready to participate in university research and teaching projects [13]. However, this study allows us to look at the problem of building constant, regular communications between the university and graduates more broadly. The question of how the experience of interacting with other graduates was built up, and what role, from the point of view of graduates, the university should play in maintaining further communication links, seems to be significant.

\section{Materials and Methods}

The human capital of graduates plays a huge role in social processes, since university education directly affects the formation of such important components of human capital as learning ability, working capacity, ability to innovate and vitality. The formation of human capital and the human resource potential of graduates is based on their professional and general cultural competencies, their attitude to studying at the university, including satisfaction with the quality of higher education. That is, everything that after graduation from the university allowed them to take one or another social position in the public hierarchy, taking into account the level of qualification and the direction of training.

The authors used the theory of human capital T.-U. Schultz and G. Becker (Schultz T.W.), the postulates of which became again relevant in the second half - the end of the twentieth century [18]. The basis of this theory is the understanding of human capital as a set of knowledge, skills, experience, motivation, as well as health, which are inherent in every person, which form an integral part of his personality. Unlike material capital, human is embodied directly in a person and cannot be transferred to someone. Maintaining human capital requires constant investment in the form of educational costs, experience, health, etc. Human capital plays an important role in the modern knowledge economy [19]. 
Also, when writing the work, the authors relied on the theory of human resource potential, which focuses on the fact that the human resource potential is a combination of human capabilities, reserves. It becomes a resource (that is, it is updated) when it can affect the change in its social status. Such types of potential are distinguished as intellectual, scientific, innovative, labor, consumer, etc. Linking these two close concepts, it can be noted that human capital is an integral element of the human resource potential model.

The practice of research at the Peter the Great St. Petersburg Polytechnic University ( $\mathrm{SPbPU}$ ) allows using the survey methods, in particular the questionnaire method, to study the human resource potential of university graduates and understands the role of the university in its formation.

\section{Results}

The following statements were formulated as hypotheses for the study:

- Studying at the university, of course, is evaluated by graduates as an activity that, in addition to teaching the profession itself, contributed to a wider disclosure of talents and the development of the graduates' abilities (see Fig. 1).

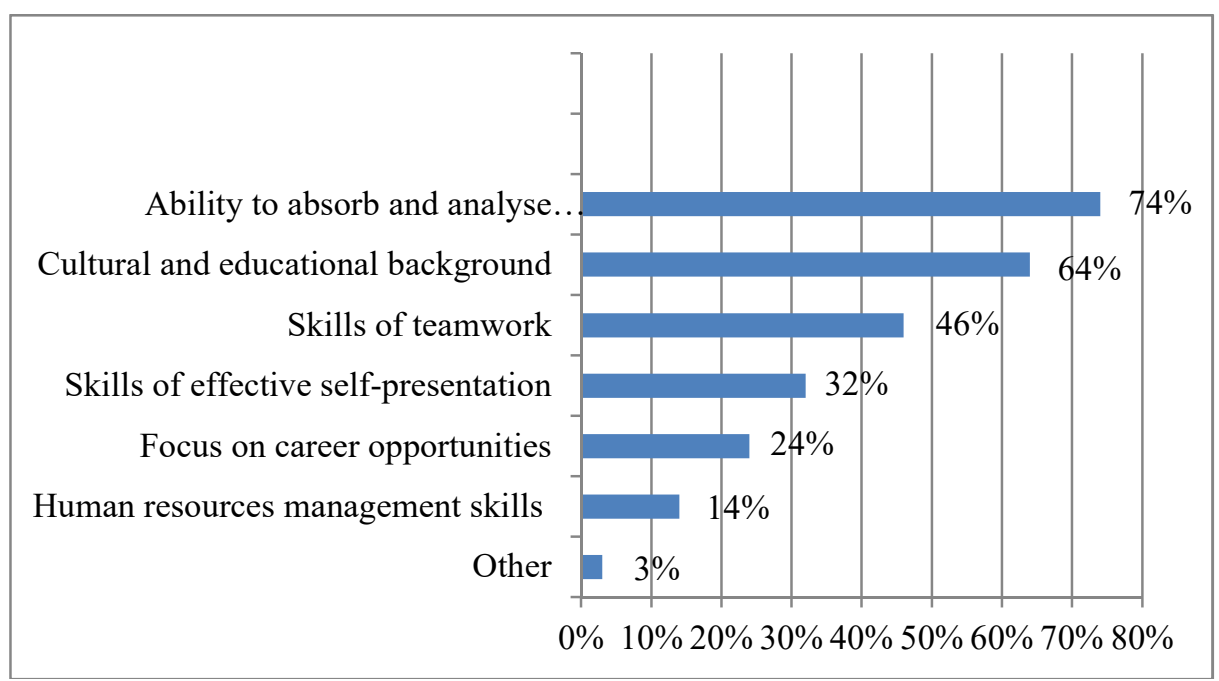

Fig. 1. What qualities did your educational and extracurricular activities at the university help you to develop? (you may choose more, than one answer)

The vast majority of respondents (74\%) noted that educational and extracurricular activities at the university helped them to develop "the ability to perceive and analyze new information, develop new ideas", which is so necessary in the modern information society and can be considered as a quality related to professional activity, requiring high mental qualifications.

From the point of view of more than half of the respondents $(64 \%)$, the university helped them with the development of "erudition, a common culture". Also, almost half of the respondents (46\%) indicated the development of the ability to "work in a team" and a third $(32 \%)$ noted the ability to "effectively represent themselves and the results of their work."

In addition, almost a quarter of graduates (24\%) pay tribute to the university in matters of raising ambitiousness and industriousness and note that the Polytech has developed in them "focus on career growth and professional development." 
Also, $14 \%$ of graduates believe that the university helped them gain managerial competencies - "personnel management skills".

Also interesting are those non-standardized answers given by graduates who chose the "Other" option, namely:

- scientific and professional competencies ( 2 answers: "the desire to do science, R\&D, the ability to analyze and think systematically from the general to the particular and from the particular to the general", "the main thing is not to be afraid of complex problems, but rather find and help solve them");

- Cognitive abilities (3 answers: "scientific thinking", "systemic thinking", "the ability to think and quickly learn new material");

- learning ability (2 answers: "learning ability", "the ability to Learn and Experiment on hypotheses, critical in the modern world");

- innovativeness ( 2 answers: "the desire to acquire new knowledge; to be in the trend and keep up to date (regarding new digital technologies, concepts, events);

- skills of analysis and work with literature ("even though I am a stage director, but in the form of structuring very complex film production processes, I was helped by training at the LPI - SPbSTU (1988 - 1994), namely working with literature and analysis of the material. Please do not accept this is a joke");

- skills "to achieve goals on time"; as one of the respondents commented, the university helped to reveal all its abilities, made it possible to develop in many directions, supported the development of business projects, tempered character;

- multitasking;

- the desire to live no matter what;

- the ability to wait;

- perseverance.

Such answers are valuable material for analysis, since they are not formulated by the researcher, but by the respondent himself.

There were also answers that negatively characterize the learning experience at the university, for example, "the university suppresses any creative rather than develops". Other respondents noted the development of such a quality as stress tolerance, but associated it with negative experiences in the process of studying at the university: "I got stress resistance after graduate school, but this is more likely due to a poorly organized structure", "self-control at the time of rudeness ...", "the ability to receive education in the absence of proper conditions", etc.

However, it was significantly less answers containing a negative assessment of experience and learning outcomes compared to positively colored ones (in total, 9 negative assessments).

If we use the question of whether graduates would like their children to repeat the beginning of their professional path and study at the Polytechnic University as an indirect evaluation, we can say that the assessment is quite high. More than half of SPbPU graduates $(64 \%)$ replied that they would like their children to study at the same university as they are. At the same time, $31 \%$ found it difficult to answer, and only 5\% answered negatively (see Fig. 2). 


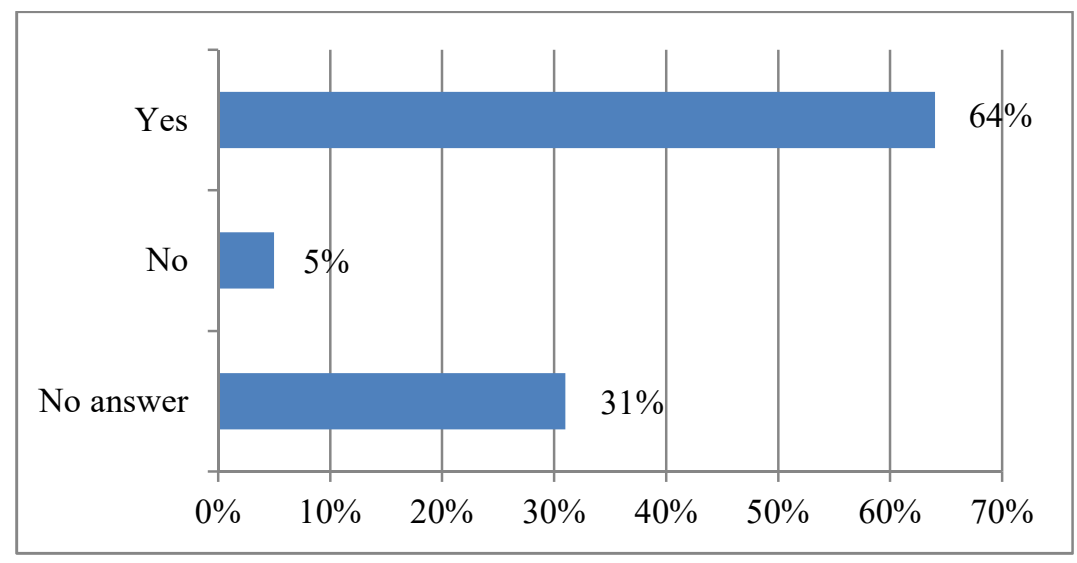

Fig. 2. Would you like your children to study at the Polytechnic?

Thus, we can conclude that the loyalty of graduates to their alma mater is quite high. This is also evidenced by the answer to the following question: "If you had to choose a specialty and educational institution again, what would you do?" (see Fig. 3).

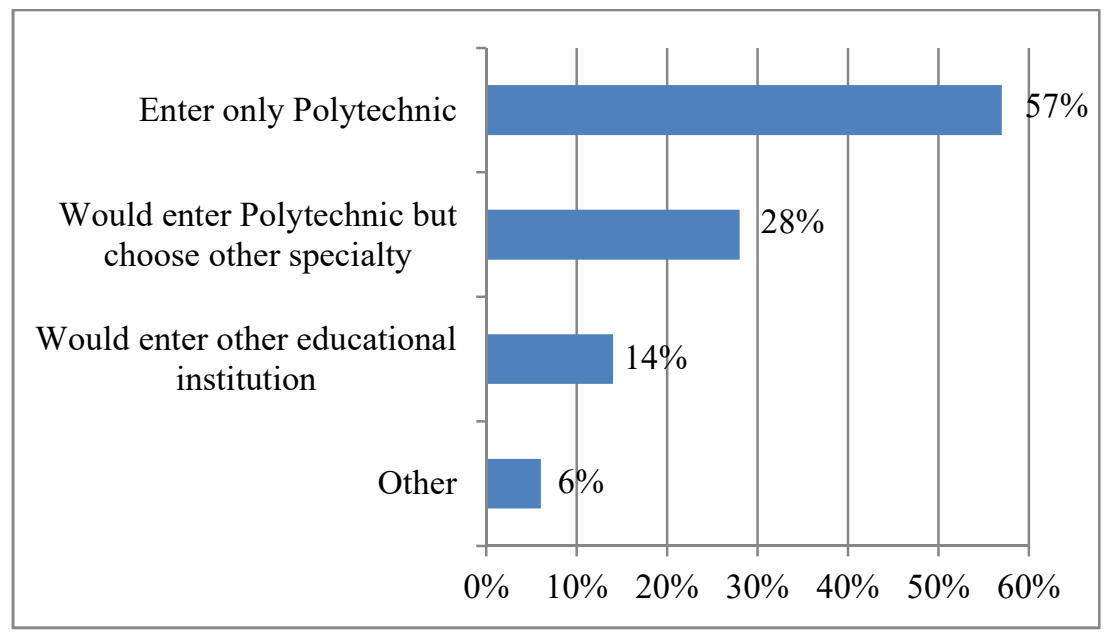

Fig. 3. If you had to choose a specialty and educational institution again, what would you do?

More than half of the respondents (57\%) replied that they would not have changed either university or specialty and would have returned only to the same place where they studied. $28 \%$ of graduates would also choose for re-entry Polytechnic University, but a different specialty. Thus, the number of graduates loyal to the university is as much as $85 \%$. Moreover, even in a changing economic situation, challenges associated with changes in the labor market and the demand for professions, we see that more than half of students consider studying in chosen in the past profession valuable enough to repeat this experience anyway.

In the field for a free answer ("Other" option), some respondents also commented as follows on their choice: "I don't know, but the Polytechnic University would be considered among the favorites", "the Polytech would be considered first of all", "I would have entered both the Polytechnic and the philological Faculty of St. Petersburg State University at the same time))), "such an option is possible", "I am happy that I received a fundamental education precisely in my specialty ...", "to the same department", "Mechanics and Control 
Processes", an indication of the family tradition of entering the Polytechnic University) and etc.

However, also in the comments there were phrases in favor of refusing to re-enter the same university, which can be divided into the following categories:

- times have changed (4 answers: "another time", "other times, how it can be compared?", "you will not enter the same river twice", "impossible to choose again :)");

- a decrease in the quality of education at St. Petersburg Polytechnic University (3 answers: "it seems to me that the quality of education in my specialty has worsened now", "it is difficult to answer. I can't enter the same river twice. I like my profession, but the quality of training has fallen ..." "It's difficult to answer, because now the Polytech is definitely not the same as during my training");

- a choice of several universities ( 3 answers: "there are many good universities. And the Polytechnic University is just one of them", "I have nothing against the Polytechnic, but I'm tormented by the MPEI," "I would consider several options, and the Polytechnic, of course , among them");

- the choice of studying abroad ( 2 answers: "I would choose to study abroad", "I would have gone abroad, if not, then would have entered the same specialty at the Polytechnic University");

- a complex of factors (7 answers: "at the Polytechnic University, but not in this form", "the choice depends largely on the level of teaching on a particular program and the level of graduation projects" "depends on the specialty and duration of study", "depends on the bonuses provided. If there would be a chance to enter another university on the budget, would prefer another university", etc.).

Studying at the university is a means of forming horizontal connections, which graduates themselves noted, answering the question about what helped them to develop educational and extracurricular activities at the university: "the most valuable thing is friends". But in addition to friendly communication, respondents noted that they were built into some horizontal network of interactions with other graduates.

So, to the question "Did you have any positive experience in interacting with other university graduates?" Only 13\% of graduates answered "no" and 1\% said that they had a negative experience (see Fig. 4).

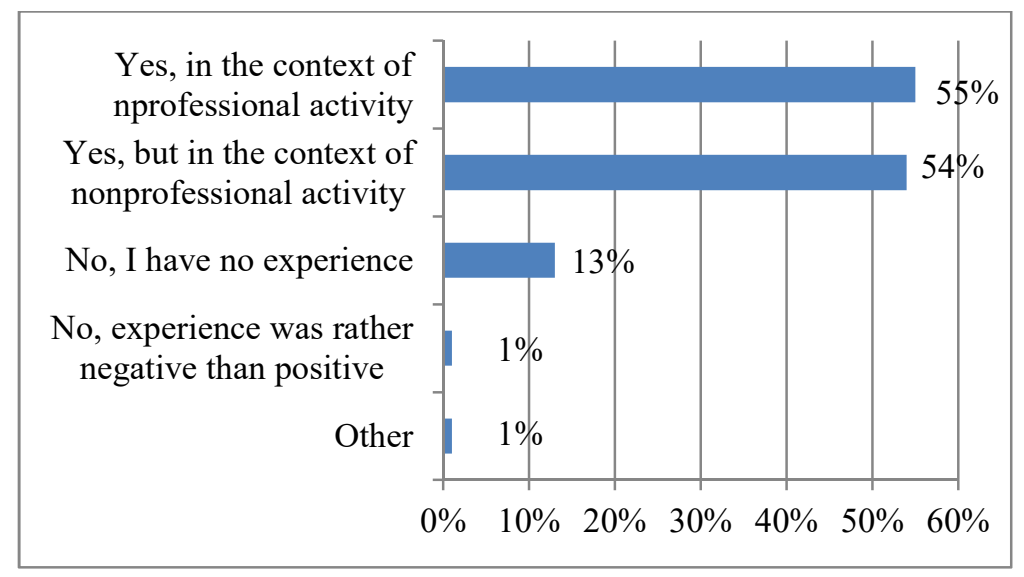

Fig. 4. Did you have any positive experience working with other SPbPU graduates?

So, $54 \%$ said they had a positive experience of interaction with other graduates that were not related to professional activities, and $55 \%$ said that they had a positive experience of cooperation in the professional field. 
Those who chose the option "other (1\%) specified the following:

- friendly communication with graduates (6 answers: "constantly in touch with their classmates", "within the company of friends", "many graduates of the Polytechnic University went into advertising in the $90 \mathrm{~s}$. We have worked with many and are still working with many with all my friends - graduates of the Polytechnic of different faculties and graduation years! ", Friends ", "wife and daughter - graduates of the Polytechnic ";

- professional communication with graduates ( 2 answers: "we work together in the same company", "I come with pleasure to the ISEM department and the graduates of my department and other departments of the Polytech work in our team, it is safer and calmer with polytechnics");

- maintaining contacts with former teachers (“yes, it was mainly our teachers").

However, as the survey shows, study at the university, helps to develop not only horizontal ties in the student community, but also vertical social ties - both with teachers and the scientific community, as well as with the professional community in the field of production and management.

Moreover, the aspect related to the fact that university graduates demonstrate their willingness to help students and young graduates to establish such vertical ties is interesting. Here we are talking specifically about vertical relationships, since we are talking about the willingness of more mature graduates to act as an assistant, curator, mentor of young graduates and students.

So, for example, a quarter of graduates $(25 \%)$ admit that they can support interesting innovative, entrepreneurial or creative projects of specific students or university graduates. At the same time, half the respondents are ready to support the university as a whole $(12 \%)$ or the projects and improvement of their department / higher school (11\%), and only $3 \%$ of graduates choose support for the Endowment Fund of the Polytechnic University.

Graduates are interested in communication and building relationships with specific people, not institutions. Based on this fact, we can hypothesize that human capital in modern society is important to the professional community. Even if they do not use such a term, nevertheless, a sufficiently large number of graduates are oriented towards the possibility of interaction and even support of young specialists and even students.

\section{Discussion}

Further discussion of the issue is dedicated to the improvement of the university communicational environment.

According to the results of the study, it can be said that an important issue is the problem of the relationship between students and the field of practical application of the knowledge and skills (business, science, public service, etc.) represented by university graduates. Based on the above figures, we can say that students are considered by already employed in business, public service, and science graduates as the same human capital, which today, in our information society, is considered as one of the fundamental tools of progress.

But students themselves also strive to increase their communication potential in order to be in demand on the labor market. Recent studies conducted among students of SPbPU (1 and 2 courses) demonstrate that students strive to use the opportunities provided by alma mater not only to obtain professional competencies, but also communicative, managerial competencies, etc., and as the most important qualities for an entrepreneur, for example, they consider leadership ability, activity, and interpersonal skills [21-23]. Also graduates, being representatives of the employer and having experience in the practical field, become for students a kind of guide to a new professional field for them. It seems that graduate clubs, internships and universities can act as a kind of social elevator for the most ambitious 
students. The emergence of practice-oriented courses and project activities at universities today is becoming a competitive advantage, which means that the proven practice of interacting with graduate customers is a matter of not only meeting the university's modern educational standards, employer requirements, but also the tasks of building effective human capital.

Thus, correlating the results of this study with studies of the student community, as well as past studies of graduates, we can conclude that we observe the mutual interest of students and graduates in each other. Such cooperation probably deserves a separate future study as one of the tools for the development of human capital, which can serve the benefit of society, industry and the university.

\section{Conclusions}

In the course of the study, the hypotheses put forward earlier were tested. The results obtained confirm the hypothesis that Polytechnic graduates perceive their alma mater as a source of the knowledge and professional skills that helped them in their career development, as well as a tool that allowed them to develop communication and managerial skills, personal qualities that also contributed to their professional success.

Graduates, for the most part, are focused on maintaining communication with the university, especially in the field of interaction with current students and graduates as a certain human capital that can be involved in solving professional problems, and which can also offer its own interesting projects.

Also, graduates demonstrated high loyalty to the university, noting, in the majority, that they would repeat their choice of alma mater and even recommend it to their children.

Interaction with the university for the graduate means the satisfaction of valuable needs for communication, self-development and self-identification. The university acts as a basic space within which a graduate can further realize his potential in the university community, form sustainable social ties and interest groups based on common experience.

Based on the analysis of the data obtained, conclusions are made about the possibilities of improving the communication between alumni and university for enhancing the professional connections with alumni and also, as we see it, the university may use the connection with alumni to improve the quality of education and in creation of human capital by getting the feedback from successful alumni, who are deep in situation of labor market and manufacturing industry and can help university to keep up with professional change.

\section{References}

1. F. Mael, B. Ashforth, Journal of Organizational Behavior J. 13(1), 103-23 (1992)

2. J.H. McAlexander, H.F. Koenig, J.W. Schouten, Journal of Marketing for Higher Education J. 14(2), 61-79 (2005) DOI: 10.1300/J050v14n02_04

3. J.T. McDearmon, Research in Higher Education J. 54(3), 283-302 (2013) DOI: 10.1007/s11162-012-9271-6

4. T. Johansen, K. Arano, Economic Development Quarterly J. 30(3), 203-214 (2016) DOI: $10.1177 / 0891242416655204$

5. M. Guerrero, J. Cunningham, D. Urbano, Research Policy J. 44, 748 (2015) DOI: 10.1016/j.respol.2014.10.008

6. N. Gennaioli, R. La Porta, F. Lopez-de-Silanes, A. Shleifer, The Quarterly Journal of Economics J. 128(1), 105-164 (2013) DOI: 10.1093/qje/qjs050

7. V. Yasvin, Proceedings of the Saratov University J. 2, 33-37 (2012) 
8. E. Razinkina, L. Pankova, I. Trostinskaya, E. Pozdeeva, L. Evseeva, A. Tanova, E3S Web of Conferences, 33, 8 (2018) DOI: 10.1051/e3sconf/20183303043

9. E. Razinkina, L. Pankova, I. Trostinskaya, E. Pozdeeva, L. Evseeva, A. Tanova, E3S Web of Conferences, 110, 02097 (2019) DOI: 10.1051/e3sconf/201911002097

10. N.N. Pokrovskaia, M.Yu. Ababkova, D.A. Fedorov, Education Sciences J. 9(3), 183 (2019) DOI: 10.3390/educsci9030183

11. E. Orekh, O. Sergeyeva, E. Bogomiagkova, International conference on Information society (I-society 2016), 7854191, 116-119 (2017). DOI: $10.1109 / \mathrm{i}-$ Society.2016.7854191

12. O. Lesher, P. Khromov, Modern problems of science and education J. 1, (2017). http://science-education.ru/ru/article/view?id=26125

13. I. Trostinskaia, D. Popov, V. Fokina, I. Obukhova, The European Proceedings of Social \& Behavioural Sciences EpSBS, LXXIII, 742-752 (2019). DOI: 10.15405/epsbs.2019.12.79

14. Y. Klyuev, V. Poznin, D. Zubko, Media Education (Mediaobrazovanie) J. 59 (2), 278285 (2019). DOI: 10.13187/me.2019.2.278

15. T. Baranova, L. Halyapina, A. Kobicheva, E. Tokareva, Educ. Sci. 9, 138 (2019) doi:10.3390/educsci9020138

16. T. Tarakanova, O. Vasileva, V. Pogodina, V. Evseev, The European Proceedings of Social \& Behavioural Sciences EpSBS. LXXIII, 917-925 (2019) DOI: 10.15405/epsbs.2019.12.96

17. E.G. Pozdeeva, O.D. Shipunova, L.I. Evseeva, IOP Conference Series: Earth and Environmental Science, 337, $012049 \quad$ (2019) DOI:DOI: 10.1088/1755$1315 / 337 / 1 / 012049$

18. T.W. Schultz, The Economic Value of Education. (New York: Columbia University Press. 1963)

19. A.V. Koritsky, Creative Economy J. 1(5), 3-10 https://cyberleninka.ru/article/n/istoki-i-osnovnye-polozheniya-teoriichelovecheskogo-kapitala/viewer

20. D.S. Bylieva, V.V. Lobatyuk, A.V. Rubtsova, IOP Conference Series: Earth and Environmental Science, 337, 012054 (2019) DOI: 10.1088/1755-1315/337/1/012054

21. I.R. Trostinskaya, E.G. Pozdeeva, L.I. Evseeva, A.G. Tanova, The European Proceedings of Social \& Behavioural Sciences EpSBS, LI, 1439-1446 (2018) doi: https://dx.doi.org/10.15405/epsbs.2018.12.02.153

22. A.S Matveevskaya, S.N. Pogodin, Vestnik of Saint Petersburg University. Philosophy and Conflict Studies J. 33 (1), 115-118 (2017) DOI: DOI: $10.21638 / 10.21638 / 11701 /$ spbu17.2017.112

23. I.R. Trostinskaia, A.S. Safonova, N.N. Pokrovskaia, Proceedings of 2017 IEEE 6th Forum Strategic Partnership of Universities and Enterprises of Hi-Tech Branches (Science. Education. Innovations), SPUE 2017, 6, 29-32 (2017) doi: 10.1109/IVForum.2017.8245961 